\title{
Ploidy Levels and Relative Genome Sizes of Species, Hybrids, and Cultivars of Dogwood (Cornus spp.)
}

\author{
Kimberly Shearer ${ }^{1,3}$ and Thomas G. Ranney ${ }^{2}$ \\ Department of Horticultural Science, North Carolina State University, \\ Mountain Crop Improvement Laboratory, Mountain Horticultural Crops \\ Research and Extension Center, 455 Research Drive, Mills River, NC 28759
}

Additional index words. cytology, DNA content, flow cytometry, interspecific hybridization, plant breeding, polyploidy

\begin{abstract}
Dogwoods (Cornus spp.) are valuable nursery crops grown as landscape plants throughout much of the world. Although there has been considerable work on breeding and selecting dogwoods, there is little information available on genome sizes (DNA content) and ploidy levels within the genus, particularly for specific clones and cultivars. Our objective was to conduct a survey of relative genome sizes and ploidy levels of dogwood taxa representative of the big-bracted, cornelian cherry, and dwarf dogwood clades. Flow cytometry was used to determine relative genome sizes and ploidy levels of 94 accessions of various species, hybrids, and cultivars. Traditional cytology was performed on root cells of representative taxa to calibrate genome sizes with ploidy level. All dogwood accessions tested were diploid with the exception of $C$. canadensis that was tetraploid and the hybrid cultivar $C$. KN30-8 that was triploid. Relative genome sizes varied by clade, subgenus, and species with $1 \mathrm{Cx}$ values ranging from $1.07 \mathrm{pg}$ for $C$. canadensis to $5.08 \mathrm{pg}$ for $C$. eydeana. Relative genome sizes were also valuable for confirming hybridity of interspecific crosses in cases in which parents varied substantially in relative genome size and hybrids were intermediate. A broad range of interspecific hybrids was documented including $C$. capitata $\times$ florida, $C$. capitata $\times$ kousa, C. elliptica $\times$ florida, $C$. hongkongensis $\times$ florida, $C$. kousa $\times$ elliptica, and $C$. kousa $\times$ florida. These results provide further insights into the cytogenetics, reproductive biology, crossability, and relative genome sizes of dogwoods.
\end{abstract}

Dogwoods include more than 50 species of shrubs, small trees, and a few herbaceous perennials with distribution that ranges across the northern hemisphere and rarely into the southern hemisphere (Eyde, 1988; Fan and Xiang, 2001; Reed, 2004; Xiang et al., 2006). Many of these species are valuable landscape plants and are frequently cultivated for their four-season attributes including attractive flowers, fruit, foliage, bark, and form (Cappiello and Shadow, 2005). According to the Census of Horticultural Specialties (USDA-NASS, 2010), 2009 sales of dogwoods totaled more than $\$ 30.9$ million in the United States.

\footnotetext{
Received for publication 5 Apr. 2013. Accepted for publication 30 Apr. 2013.

This research was funded, in part, by the North Carolina Agricultural Research Service (NCARS), Raleigh, NC, the North Carolina Biotechnology Center, Research Triangle Park, NC, the Kenan Institute, Chapel Hill, NC, and the North Carolina Nursery and Landscape Association, Raleigh, NC. Technical assistance of Nathan Lynch, Joel Mowrey, Tom Eaker, Jeremy Smith, and Jason Lattier is gratefully acknowledged. We also thank Dr. Thomas Molnar at Rutgers University for providing samples of Cornus 'KN30-8' (Venus ${ }^{\mathrm{TM}}$ ). ${ }^{1}$ Undergraduate Research Intern.

${ }^{2}$ Professor.

${ }^{3}$ To whom reprint requests should be addressed; e-mailkmsheare@ncsu.edu.
}

Considerable research has focused on determining the systematic relationships among dogwoods (Fan and Xiang, 2001, 2003; Xiang et al., 1993, 1996, 1998, 2002, 2006). A specieslevel phylogeny completed by Xiang et al. (2006), supported major clades within the genus including the big-bracted dogwoods (BB) comprising subgenus Cynoxylon and Syncarpea, the dwarf dogwoods (DW) comprising subgenus Arctocrania, and the cornelian cherries (CC) comprising subgenus Cornus.

Polyploidy, also referred to as whole genome duplication, has played a significant role in the evolution and diversification of angiosperms (Soltis and Burleigh, 2009; Soltis et al., 2004, 2009). Polyploidization may lead to reproductive isolation, rapid genomic rearrangements, novel patterns of gene expression, and adaptations, which can ultimately lead to divergence and speciation (Adams and Wendel, 2005; Comai, 2005; Hegarty and Hiscock, 2008; Soltis and Burleigh, 2009). Knowledge of ploidy levels is important for plant breeders because it can influence fertility, crossability, segregation, and gene expression (Chen and $\mathrm{Ni}, 2006$; Soltis et al., 2004). Cytological studies on dogwoods have found the base chromosome number for BB to be $x=11$, for CC to be $x=$ nine or 10 , and for DW to be $x=11$ with both diploids and tetraploids found in the DW (Dermen, 1932; Goldblatt, 1978; Xiang and Eyde, 1995; Xiang et al., 2006). Chromosome counts for $C$. canadensis (DW) vary and include diploid ( $2 n=2 x=22$ ) (Murrell, 1994; Packer, 1964; Zhang et al., 2008) and tetraploid $(2 n=4 x=44)$ (Dermen, 1932; Löve and Löve, 1982) assessments.

Genome size data reflect fundamental biodiversity characters and can be reflective of genome evolution and taxonomic relationships (Greilhuber, 1998; Rounsaville and Ranney, 2010; Zonneveld and Duncan, 2010; Zonneveld et al., 2005). Genome size data can also be used to determine ploidy levels among closely allied species when properly calibrated (Jones et al., 2007; Palmer et al., 2009; Parris et al., 2010; Rounsaville and Ranney, 2010). In some cases, when parents vary considerably in genome sizes, hybrids can be verified based on intermediate values (Galbraith et al., 2005; Keller et al., 1996; Parris et al., 2010).

Despite the considerable breeding, selection, and widespread cultivation of dogwoods, sampling for genome size and ploidy level of species, cultivars, and hybrids has been limited and little is known concerning ploidy level and genome size of specific cultivars and hybrids. The objectives of this study were to determine relative genome sizes and ploidy levels of diverse taxa within Cornus, specifically for the BB, CC, and DW clades.

\section{Materials and Methods}

Flow cytometry. Relative 2C genome sizes were determined using flow cytometry (Greilhuber et al., 2007). Plant tissue, including expanding leaf tissue, vegetative buds, and floral buds, was collected from 94 accessions (Table 1) at the Mountain Horticultural Crop Research and Extension Center of North Carolina State University located in Mills River, NC. These included nine species and seven groups of hybrids representing $\mathrm{BB}, \mathrm{CC}$, and $\mathrm{DW}$ dogwoods that were sampled over time (May 2012 through Mar. 2013) in a completely randomized design. In addition, leaf tissue from the original Cornus 'KN30-8' (Venus ${ }^{\mathrm{TM}}$ ) was provided by Dr. Thomas Molnar at Rutgers University. Approximately $1 \mathrm{~cm}^{2}$ or $20 \mathrm{mg}$ of tissue was finely chopped in a polystyrene petri dish with $400 \mu \mathrm{L}$ of nuclei extraction buffer (CyStain ultraviolet Precise P Nuclei Extraction Buffer; Partec, Münster, Germany) using a sharp razor blade. The nuclei suspension was then filtered through $50-\mu \mathrm{m}$ nylon filters and stained using $1.6 \mathrm{~mL} \mathrm{4}{ }^{\prime}, 6$ diamidino-2-phenylindole (DAPI) staining buffer (Cystain ultraviolet Precise P Staining Buffer; Partec). Relative genome size was determined using a flow cytometer with fluorescence excitation provided by a mercury arc lamp (Partec PA-I; Partec). A minimum of 3000 nuclei was analyzed for each sample with a maximum $\mathrm{CV}$ of $4 \%$, though it was typically below 3\%. Pisum sativum 'Ctirad' (absolute $2 \mathrm{C}=8.75 \mathrm{pg}$ ) was used as an internal standard for most taxa based on its common use as a reference standard (Bai et al., 2012; Greilhuber et al., 2007) and because its genome size was similar but distinct from most Cornus spp. As a result of the large 


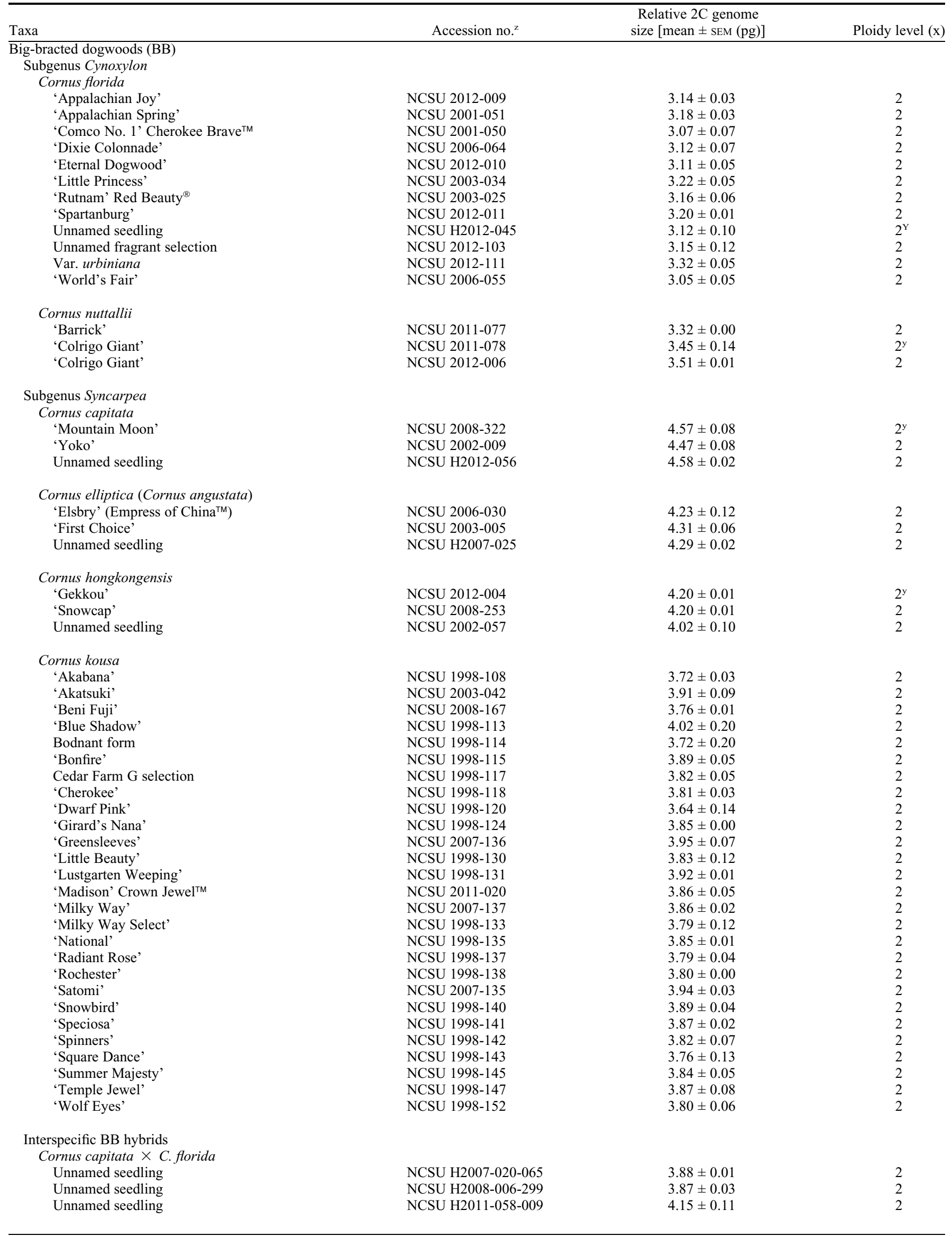


Table 1. (Continued) Relative genome sizes and ploidy levels, determined using flow cytometry, for species, hybrids, and cultivars of Cornus.

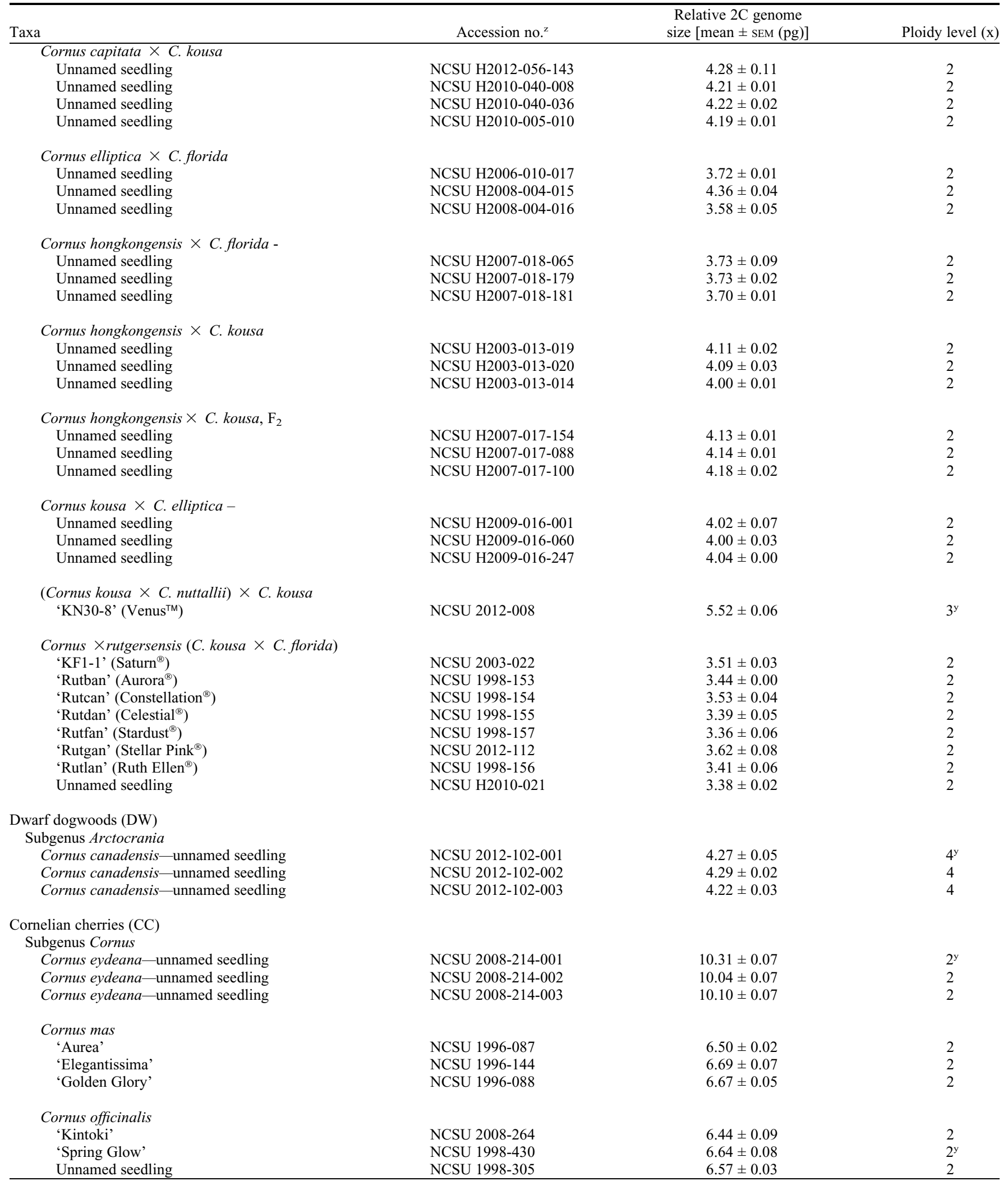

${ }^{\mathrm{z}}$ Accession number from the North Carolina State University, Mountain Crop Improvement Laboratory, Mills River, NC.

'Indicates ploidy was confirmed with cytology.

relative genome size of C. eydeana, Magnolia virginiana 'Jim Wilson' (Moonglow ${ }^{\mathrm{TM}}$ ) was used as an internal standard (absolute $2 \mathrm{C}=$ $3.92 \mathrm{pg}$ ) for those analyses following Parris et al. (2010). Internal standards were cochopped with samples during nuclei extraction.
Holoploid, 2C DNA contents were calculated as: $2 \mathrm{C}=\mathrm{DNA}$ content of standard $\times$ (mean fluorescence value of sample $\div$ mean fluorescence value of the standard). Analyses were completed on two subsamples for each replicate. The relationship between ploidy level and genome sizes was initially determined for species with documented chromosome numbers (Harrington et al., 1985; Li and Shang, 2002; Sandhu and Mann, 1988). Mean 1Cx monoploid genome size (i.e., DNA content of the non-replicated 
Table 2. Monoploid genome sizes (1Cx), determined using flow cytometry, for Cornus spp., grouped by clade, subgenus, and species/grex.

\begin{tabular}{|c|c|c|c|c|c|}
\hline Clade & $1 \mathrm{Cx}(\mathrm{pg})$ & Subgenus & $1 \mathrm{Cx}(\mathrm{pg})$ & Species/grex & $1 \mathrm{Cx}(\mathrm{pg})$ \\
\hline \multirow[t]{3}{*}{ Cornelian cherries $(\mathrm{CC})$} & $3.88 \pm 0.30 \mathrm{~A}^{\mathrm{z}}$ & Cornus & $3.89 \pm 0.30 \mathrm{~A}$ & C. eydeana & $5.08 \pm 0.04 \mathrm{~A}$ \\
\hline & & & & C. mas & $3.31 \pm 0.03 \mathrm{~B}$ \\
\hline & & & & C. officinalis & $3.28 \pm 0.03 \mathrm{~B}$ \\
\hline \multirow[t]{14}{*}{ Big-bracted dogwoods (BB) } & $1.89 \pm 0.02 \mathrm{~B}$ & Syncarpea & $2.00 \pm 0.02 \mathrm{~B}$ & C. capitata & $2.27 \pm 0.05 \mathrm{C}$ \\
\hline & & & & C. elliptica & $2.14 \pm 0.01 \mathrm{D}$ \\
\hline & & & & C. hongkongensis & $2.07 \pm 0.03 \mathrm{DE}$ \\
\hline & & & & C. kousa & $1.92 \pm 0.01 \mathrm{HI}$ \\
\hline & & & & C. capitata $\times$ C. kousa & $2.11 \pm 0.01 \mathrm{D}$ \\
\hline & & & & C. hongkongensis $\times$ C. kousa & $2.03 \pm 0.02 \mathrm{EF}$ \\
\hline & & & & C. hongkongensis $\times$ C. kousa, $\mathrm{F}_{2}$ & $2.08 \pm 0.01 \mathrm{DE}$ \\
\hline & & & & C. kousa $\times C$. elliptica & $2.01 \pm 0.01 \mathrm{EFG}$ \\
\hline & & Syncarpea $\times$ Cynoxylon & $1.83 \pm 0.03 \mathrm{BC}$ & C. capitata $\times$ C. florida & $1.98 \pm 0.05 \mathrm{FGH}$ \\
\hline & & & & C. hongkongensis $\times C$. florida & $1.86 \pm 0.01 \mathrm{I}$ \\
\hline & & & & C. elliptica $\times$ C. florida & $1.94 \pm 0.12 \mathrm{GH}$ \\
\hline & & & & C. $\times$ rutgersensis & $1.73 \pm 0.02 \mathrm{~J}$ \\
\hline & & Cynoxylon & $1.60 \pm 0.02 \mathrm{C}$ & C. florida & $1.58 \pm 0.01 \mathrm{~K}$ \\
\hline & & & & C. nuttallii & $1.71 \pm 0.03 \mathrm{~J}$ \\
\hline Dwarf dogwoods (DW) & $1.07 \pm 0.01 \mathrm{C}$ & Arctocrania & $1.07 \pm 0.01 \mathrm{D}$ & C. canadensis & $1.07 \pm 0.01 \mathrm{~L}$ \\
\hline
\end{tabular}

${ }^{\mathrm{z}}$ Values followed by different letters within a column are significantly different, least significant difference, $P \leq 0.05$.

base set of chromosomes) was calculated as $2 \mathrm{C}$ genome size $\div$ ploidy level.

Cytology. Cytology was used to verify chromosome numbers and ploidy levels of eight taxa representing different taxonomic groups and to further calibrate genome sizes with ploidy levels (Table 1). Actively growing root tips, $\approx 10 \mathrm{~mm}$ in length, were collected from seedlings and rooted stem cuttings in the mornings before $1000 \mathrm{HR}$. Root tips were suspended in a pre-fixative solution of $2 \mathrm{~mm}$ 8-hydroxyquinoline $+0.24 \mathrm{~mm}$ cycloheximide in glass vials and stored in the dark at room temperature for $3 \mathrm{~h}$. Root tips were then refrigerated at $6{ }^{\circ} \mathrm{C}$ for $3 \mathrm{~h}$ in the dark. After pre-fixative treatment, root tips were rinsed four times using refrigerated distilled $\mathrm{H}_{2} \mathrm{O}$ and then placed into a fixative solution of three parts $95 \%$ ethanol:one part propionic acid. Samples were then stored at room temperature overnight. The next morning, root tips were rinsed four times using $70 \%$ ethanol and stored in vials of $70 \%$ ethanol until needed.

Before squashing, root tip cell walls were hydrolyzed using three $95 \%$ ethanol:one $12 \mathrm{M}$ hydrochloric acid for $\approx 3 \mathrm{~min}$. After hydrolysis, root tips were then placed into a staining solution of modified carbol fuschin (Kao, 1975 ) for $\approx 5 \mathrm{~min}$. The distal end of the stained root tip was excised under a dissecting microscope (Leica Stereozoom 6 Photo, Buffalo Grove, IL) and then placed on a glass microscope slide and gently squashed with a coverslip. Chromosomes were viewed using a light microscope (Nikon Eclipse 80i, Melville, NY).

Data for monoploid genome sizes $(1 \mathrm{Cx})$ were subjected to analysis of variance by clade, subgenus, and species/grex, and means were separated using Fisher's least significant difference (Proc GLM; SAS Version 9.2; SAS Inst., Cary, NC).

\section{Results and Discussion}

Flow cytometry was an effective, efficient, and consistent method for determining relative genome sizes and ploidy levels of Cornus (Table 1). Values for the two subsamples of each replicate were consistent with SEMS for $2 \mathrm{C}$ values ranging from less than 0.01 to $0.2 \mathrm{pg}$ with a mean of $0.05 \mathrm{pg}$. Few studies have reported genome sizes in Cornus, although Bai et al. (2012) reported the $2 \mathrm{C}$ value of one sample of $C$. canadensis as $4.4 \mathrm{pg}$ [using propidium iodide (PI) stain] that is close to our findings that ranged from 4.2 to $4.3 \mathrm{pg}$ (using DAPI stain). Zonneveld et al. (2005) found the $2 \mathrm{C}$ value of one sample of C. mas as $6.8 \mathrm{pg}$ (using PI stain) similar to our values that ranged from 6.5 to $6.7 \mathrm{pg}$ (using DAPI stain). Although different fluorochrome stains may give slightly different estimates of genome size (Doležel and Bartoš, 2005), both PI and DAPI have been found to be effective and consistent for determining and comparing ploidy levels and relative genome size among closely related taxa (Parris et al., 2010). Furthermore, the DAPI procedure is faster, less expensive, uses less toxic compounds, and typically produces results with a lower $\mathrm{CV}$ for mean nuclei fluorescence. Our estimates of $2 \mathrm{C}$ values for $C$. florida ranged from 3.05 to $3.32 \mathrm{pg}$, which was considerably higher than estimates of 2.19 to $2.77 \mathrm{pg}$ reported by Wang et al. (2009), although both studies used DAPI stain.

Monoploid genome sizes $(1 \mathrm{Cx})$ varied among clades, subgenera, and species and ranged from $1.07 \mathrm{pg}$ for $C$. canadensis to $5.16 \mathrm{pg}$ for $C$. eydeana and were very consistent within species/grex with SEMS ranging from 0.01 to $0.12 \mathrm{pg}$ and a mean SEM of $0.03 \mathrm{pg}$ (Table 2). Based on the taxa sampled, mean $1 \mathrm{Cx}$ values were smallest for the DW at $1.07 \mathrm{pg}$, the $\mathrm{BB}$ were intermediate at $1.89 \mathrm{pg}$, and the $\mathrm{CC}$ were considerably larger at $3.88 \mathrm{pg}$ (Table 2).

There were also differences among subgenera within clades. For the BB dogwoods, mean $1 \mathrm{Cx}$ values for subgenus Syncarpea $(2.00 \mathrm{pg})$ were significantly higher than for subgenus Cynoxylon (1.60 pg), whereas hybrids between these two subgenera were intermediate $(1.83 \mathrm{pg})$. In some cases, there

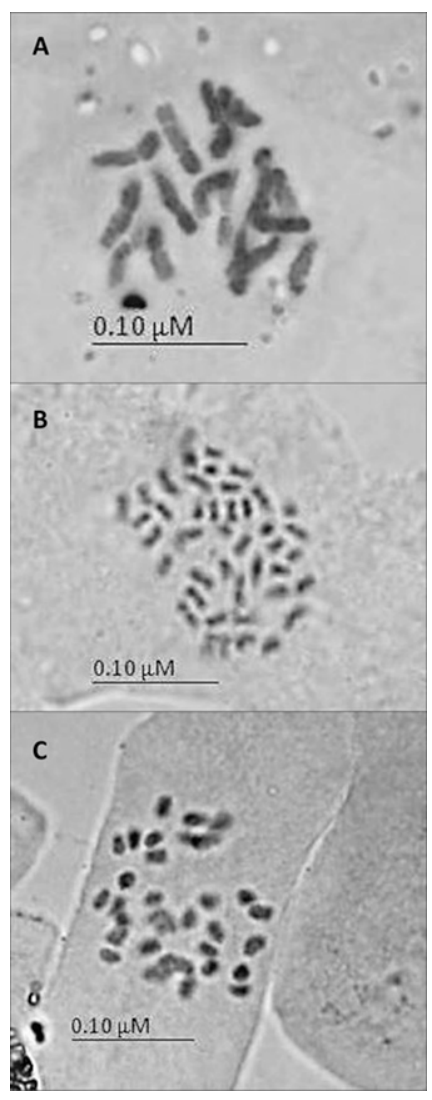

Fig. 1. Photomicrographs of somatic chromosomes of (A) Cornus eydeana $(2 n=2 x=18),($ B $) C$. canadensis $(2 n=4 x=44)$, and $(\mathbf{C}) C$. ' $\mathrm{KN} 30-8$ ' Venus $^{\mathrm{TM}}(2 n=3 x=33)$.

were also differences in $1 \mathrm{Cx}$ values among species within subgenera. For example, within subgenus Cornus, C. eydeana was significantly larger (5.08 pg) than C. mas (3.31 pg) and $C$. officinalis $(3.28 \mathrm{pg})$. Also, within subgenus Cynoxylon, C. florida had a $1 \mathrm{Cx}$ mean of 1.58 $\mathrm{pg}$, whereas $C$. nuttallii was significantly larger with a $1 \mathrm{Cx}$ mean of $1.71 \mathrm{pg}$. Monoploid genome sizes of evergreen species within Syncarpea 


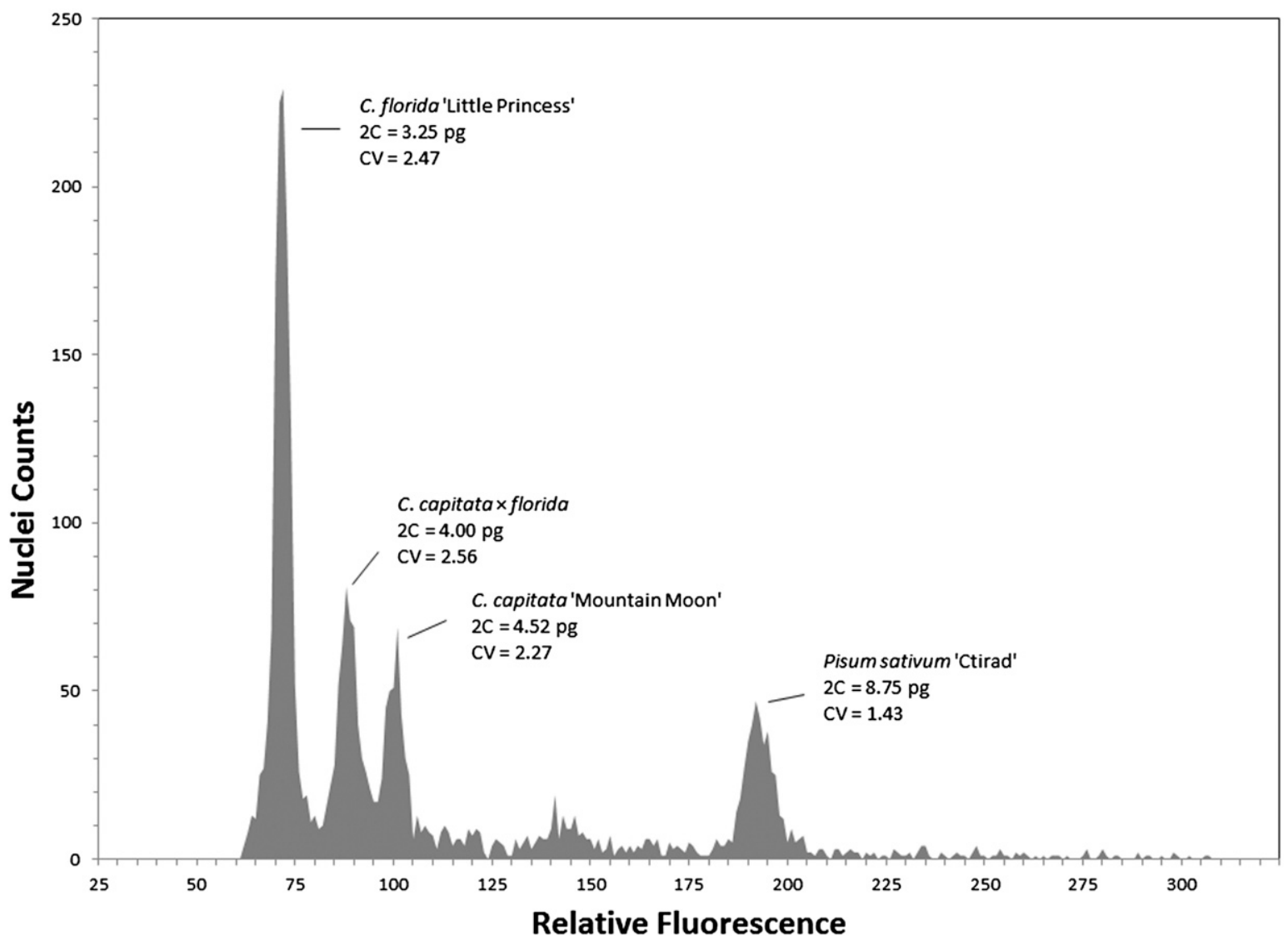

Fig. 2. Cytometer histogram showing relative fluorescence peaks of 4', 6-diamidino-2-phenylindole-stained nuclei and calculated relative 2C genome sizes and cV for Cornus florida, C. capitata, their interspecific hybrid, and Pisum sativum 'Ctirad' as an internal standard.

(e.g., C. capitata, elliptica, and hongkongensis) varied some with $C$. capitata having the largest mean of $2.27 \mathrm{pg}$, and all of these species had significantly larger $1 \mathrm{Cx}$ values ( 2.07 to $2.27 \mathrm{pg}$ ) than that of $C$. kousa $(1.92 \mathrm{pg})$. These results support the taxonomic groupings developed by Xiang et al. (2006) because the range of genome sizes for each of the subgenera and clades are distinct and discontinuous.

Cytological and cytometrical analyses confirmed that the majority of taxa tested were diploid (Table 1). Even C. eydeana, with a particularly large 2C genome size of 10.31 pg, was $2 n=2 x=18$ (Fig. 1A). The only tetraploid found was $C$. canadensis with $2 n=$ $4 x=44$ (Fig. 1B). There are conflicting reports on the ploidy level of $C$. canadensis. Dermen (1932) and Löve and Löve (1982) also found $C$. canadensis to be a tetraploid; however, other studies have suggested that the only tetraploid species of the genus is C. unalaschkensis (Zhang et al., 2008), a putative allopolyploid hybrid between $C$. canadensis and C. suecica (Murrell, 1994). Considering the widespread distribution of $C$. canadensis (Xiang and Boufford, 2005), there may be a ploidy series within the species. Ploidy series are commonly found within species, some of which exhibit ploidy varying with distribution (Baack, 2004; Burton and Husband, 1999; Hardy and Vekemans, 2001; Li et al., 2010; Nakagawa, 2006; Whittemore and Olsen, 2011), whereas others exhibit ploidy heterogeneity within populations (Halverson et al., 2008; Trávníček et al., 2011)

The only triploid identified in this study was the interspecific hybrid $C$. 'KN30-8' (NCSU 2012-008), [(C. kousa $\times$ C. nuttallii $) \times$ C. kousa], with $2 n=3 x=33$ (Fig. 1C). It has been noted that hybrids often produce unreduced gametes at a particularly high frequency (Ramsey and Schemske, 1998), which may have contributed to the formation of this rare polyploidy in the $\mathrm{BB}$ clade. There has previously been some speculation that C. officinalis 'Spring Glow' may be a triploid based on its extremely low fruit set (personal observation), though its relative genome size is consistent with other diploids. It is also interesting to note that $\mathrm{F}_{1}$ hybrids of C. kousa $\times$ C. elliptica retain fertility (personal observation) though the parents vary in genome size by over $11 \%$.

Relative genome sizes were also valuable for confirming hybridity of interspecific crosses in cases in which parents varied substantially in genome size (Fig. 2). Hybrids between species in the subgenera Syncarpea and Cynoxylon were readily apparent based on intermediate genome sizes including: C. capitata $\times$ C. florida, $C$. hongkongensis $\times$ C. florida, C. elliptica $\times$ C. florida, and C. $\times$ rutgersensis (Table 2 ). In some cases, interspecific hybrids within subgenus $\mathrm{Syn}$ carpea could also be confirmed, including C. capitata $\times$ C. kousa and C. kousa $\times C$. elliptica, though relative genome sizes were too similar between $C$. hongkongensis and C. kousa to verify hybrids between those species. Confirmation of these hybrids further suggests that there is considerable potential for the development of new hybrids among diverse species of BB dogwoods.

This study provides new and pertinent information on genome sizes and ploidy levels for species, cultivars, and hybrids of dogwoods. Additionally, it was found that genome size data can be an efficient and effective means of confirming hybridization among many BB dogwood species. These results provide further insights into the cytogenetics, systematics, reproductive biology, and crossability of dogwoods and contribute to the larger census of genome sizes of angiosperms.

\section{Literature Cited}

Adams, K.L. and J.F. Wendel. 2005. Novel patterns of gene expression in polyploid plants. Trends Genet. 21:539-543.

Baack, E.J. 2004. Cytotype segregation on regional and microgeographic scales in snow buttercups (Ranunculus adoneus: Ranunculaceae). Amer. J. Bot. 91:1783-1788.

Bai, C., W.S. Alverson, A. Follansbee, and D.M. Waller. 2012. New reports of nuclear DNA content for 407 vascular plant taxa from the United States. Ann. Bot. (Lond.) 110:16231629.

Burton, T.L. and B.C. Husband. 1999. Population cytotype structure in the polyploid Galax 
urceolata (Diapensiaceae). Heredity 82:381390.

Cappiello, P. and D. Shadow. 2005. Dogwoods: The genus Cornus. Timber Press, Portland, OR.

Chen, Z.J. and Z. Ni. 2006. Mechanisms of genomic rearrangements and gene expression changes in plant polyploids. Bioessays 28:240-252.

Comai, L. 2005. The advantages and disadvantages of being polyploid. Nat. Rev. Genet. 6(11):836846.

Dermen, H. 1932. Cytological studies of Cornus. J. Arnold Arbor. 13:410-417.

Doležel, J. and J. Bartoš. 2005. Plant DNA flow cytometry and estimation of nuclear genome size. Ann. Bot. (Lond.) 95:99-110.

Eyde, R.H. 1988. Comprehending Cornus: Puzzles and progress in the systematics of the dogwoods. Bot. Rev. 54:233-351.

Fan, C. and J.Q. Xiang. 2001. Phylogenetic relationships within Cornus (Cornaceae). Amer. J. Bot. 88:1131-1138.

Fan, C. and J.Q. Xiang. 2003. Phylogenetic analyses of Cornales based on 26S rDNA and combined 26S rDNA-matK-rbcL sequence data. Amer. J. Bot. 90:1357-1372.

Galbraith, D.W., J. Bartos, and J. Doležel. 2005. Flow cytometry and cell sorting in plant biotechnology, p. 291-322. In: Sklar, L.A. (ed.). Flow cytometry in biotechnology. Oxford Univ. Press, New York, NY.

Goldblatt, P. 1978. A contribution to cytology in Cornales. Ann. Mo. Bot. Gard. 65:650-655.

Greilhuber, J. 1998. Intraspecific variation in genome size: A critical reassessment. Ann. Bot. (Lond.) 82:27-35.

Greilhuber, J., E.M. Temsch, and J.C.M. Loureiro. 2007. Nuclear DNA content measurement, p. 67-101. In: Doležel, J., J. Greilhuber, and J. Suda (eds.). Flow cytometry with plant cells: Analysis of genes, chromosomes and genomes. WILEY-VCH Verlag GmbH \& Co., KGaA, Weinheim, Germany.

Halverson, K., S.B. Heard, J.D. Nason, and J.O. Stireman, III. 2008. Origins, distribution, and local co-occurrence of polyploid cytotypes in Solidago altissima (Asteraceae). Amer. J. Bot. 95:50-58.

Hardy, O.J. and X. Vekemans. 2001. Patterns of allozyme variation in diploid and tetraploid Centaurea jacea at different spatial scales. Evolution 55:943-954.

Harrington, E., E.R. Orton, Jr., and G. Jelenkovic. 1985. Pachytene morphology of the chromosome complement in Cornus florida 'Sweetwater' Cytologia (Tokyo) 50:9-19.

Hegarty, M.J. and S.J. Hiscock. 2008. Genomic clues to the evolutionary success of polyploidy plants. Curr. Biol. 18:R435-R444.

Jones, J.R., T.G. Ranney, and N.P. Lynch. 2007. Ploidy levels and relative genome sizes of diverse species, hybrids, and cultivars of Rhododendron. J. Amer. Rhododendron Soc. 61:220-227.

Kao, K.N. 1975. A chromosomal staining method for cultured cells, p. 63-64. In: Gambourg, O.L. and L.R. Wetter (eds.). Plant tissue culture methods. NRC Canada, Saskatoon, Canada.

Keller, E.R.J., L. Schubert, J. Fuchs, and A. Meister. 1996. Interspecific crosses of onion with distant Allium species and characterization of the presumed hybrids by means of flow cytometry, karyotype analysis and genomic in situ hybridization. Theor. Appl. Genet. 92:417424.

Li, D., Y. Liu, C. Zhong, and H. Huang. 2010. Morphological and cytotype variation of wild kiwifruit (Actinidia chinensis complex) along an altitudinal and longitudinal gradient in central-west China. Bot. J. Linn. Soc. 164: 72-83.

Li, R.J. and Z.Y. Shang. 2002. Karyotypes of five species of Cornus (s.1.) (Cornaceae) from China. Acta. Phytotax. Sin. 40:357-363.

Löve, Á. and D. Löve. 1982. IOPB chromosome number reports LXXV. Taxon 31:342-386.

Murrell, Z.E. 1994. Dwarf dogwoods: Intermediacy and the morphological landscape. Syst. Bot. 19:539-556.

Nakagawa, M. 2006. Ploidy, geographical distribution and morphological differentiation of Parasenecio auriculata (Senecioneae; Asteraceae) in Japan. J. Plant Res. 119:51-61.

Packer, J.G. 1964. Chromosome numbers and taxonomic notes on western Canadian and Arctic plants. Can. J. Bot. 42:473-494.

Palmer, I.E., R.E. Bir, N.P. Lynch, and T.G. Ranney. 2009. Crossability, cytogenetics, and reproductive pathways in Rudbeckia subgenus Rudbeckia. HortScience 44:44-48.

Parris, J.K., T.G. Ranney, H.T. Knap, and W.V. Baird. 2010. Ploidy levels, relative genome sizes, and base pair composition in Magnolia. J. Amer. Soc. Hort. Sci. 135:533-547.

Ramsey, J. and D.W. Schemske. 1998. Pathways, mechanisms, and rates of polyploid formation in flowering plants. Annu. Rev. Ecol. Syst. 29: 467-501.

Reed, S.M. 2004. Self-incompatibility in Cornus florida. HortScience 39:335-338.

Rounsaville, T.J. and T.G. Ranney. 2010. Ploidy levels and genome sizes of Berberis L. and Mahonia Nutt. species, hybrids, and cultivars. HortScience 45:1029-1033.

Sandhu, P.S. and S.K. Mann. 1988. SOCGI plant chromosome number reports-VII. J. Cytol. Genet. 23:219-228.

Soltis, D.E. and J.G. Burleigh. 2009. Surviving the K-T mass extinction: New perspectives of polyploidization in angiosperms. Proc. Natl. Acad. Sci. U S A 106:5455-5456.

Soltis, D.E., V.A. Albert, J. Leebens-Mack, C.D. Bell, A.H. Paterson, C. Zheng, D. Sankoff, C.W. DePamphilis, P.K. Wall, and P.S. Soltis. 2009. Polyploidy and angiosperm diversification. Amer. J. Bot. 96:336-348.

Soltis, D.E., P.S. Soltis, and J.A. Tate. 2004. Advances in the study of polyploidy since Plant speciation. New Phytol. 161:173-191.

Trávníček, P., B. Kubátová, V. Čurn, J. Rauchová, E. Krajníkova, J. Jersáková, and J. Suda. 2011.
Remarkable coexistence of multiple cytotypes of the Gymnadenia conopsea aggregate (the fragrant orchid): Evidence from flow cytometry. Ann. Bot. (Lond.) 107:77-87.

USDA-NASS. 2010. Census of horticultural specialties (2009), Table 21: Deciduous flowering trees. Aug. 2012. <http://www.agcensus.usda. gov/Publications/2007/Online_Highlights/Census_ of_Horticulture_Specialties/ $>$.

Wang, X., P.A. Wadl, T.A. Rinehart, B.E. Scheffler, M.T. Windham, J.M. Spiers, D.H. Johnson, and R.N. Trigiano. 2009. A linkage map for flowering dogwood (Cornus florida L.) based on microsatellite markers. Euphytica 165:165175.

Whittemore, A.T. and R.T. Olsen. 2011. Ulmus americana (Ulmaceae) is a polyploidy complex. Amer. J. Bot. 98:1-7.

Xiang, J.Q. and D.E. Boufford. 2005. Cornaceae (Dumortier) Dumortier Flora China 14:206-221.

Xiang, J.Q., S.J. Brunsfeld, D.E. Soltis, and P.S. Soltis. 1996. Chloroplast DNA phylogeny of Cornus L. (Cornaceae) and its implications for biogeography and character evolution. Syst. Bot. 21:515-534.

Xiang, J.Q. and R.H. Eyde. 1995. Chromosome number of Cornus sessilis (Cornaceae): Phylogenetic affinity and evolution of chromosome numbers in Cornus. Sida 16:765-768.

Xiang, J.Q., M. Moody, D.E. Soltis, C.Z. Fan, and P.S. Soltis. 2002. Relationships within Cornales and circumscription of Cornaceae-matK and $\mathrm{rbcL}$ sequence data and effects of outgroups and long branches. Mol. Phylogenet. Evol. 24:35-57.

Xiang, J.Q., D.E. Soltis, D.R. Morgan, and P.S. Soltis. 1993. Phylogenetic relationships of Cornus L. sensu lato and putative relatives inferred from rbcL sequence data. Ann. Mo. Bot. Gard. 80:723-734.

Xiang, J.Q., D.E. Soltis, and P.S. Soltis. 1998. Phylogenetic relationships of Cornaceae and close relatives inferred from matK and $\mathrm{rbcL}$ sequences. Amer. J. Bot. 85:285-297.

Xiang, J.Q., D.T. Thomas, W.H. Zhang, S.R. Manchester, and Z. Murrell. 2006. Species level phylogeny of the dogwood genus Cornus (Cornaceae) based on molecular and morphological evidence-Implication in taxonomy and Tertiary intercontinental migration. Taxon 55:9-30.

Zhang, W., J.Q. Xiang, D.T. Thomas, B.M. Wiegmann, M.W. Frohlich, and D.E. Soltis. 2008. Molecular evolution of PISTILLATAlike genes in the dogwood genus Cornus (Cornaceae). Mol. Phylogenet. Evol. 47:175-195.

Zonneveld, B.J.M. and G.D. Duncan. 2010. Genome sizes of Eucomis L'He'r. (Hyacinthaceae) and a description of the new species Eucomis grimshawii G.D. Duncan \& Zonneveld. Plant Syst. Evol. 284:99-109.

Zonneveld, B.J.M., I.J. Leitch, and M.D. Bennett. 2005. First nuclear DNA amounts in more than 300 angiosperms. Ann. Bot. (Lond.) 96:229244. 